\title{
DA CORRELAÇÁO ENVOLVENDO O ASPECTO HISTÓRICO DA ESCRITURA \\ E O SU CARÁTER DE LOGOS ENTRE O KERYGMA E O PROCESSO DE DESMITOLOGIZAÇÁO EM RUDOLF BULTMANN SEGUNDO PAUL RICOEUR
}

On The Correlation Involving the Historical Aspect of the Scripture and Its Logos Character between Kerygma and the Demythologization Process in Rudolf Bultmann According To Paul Ricoeur

Sobre la correlación que involucra el aspecto histórico de la escritura y su carácter de Logos entre Kerigma y el proceso de desmitologización en Rudolf Bultmann según Paul Ricoeur

Luiz Carlos Mariano Da Rosa ${ }^{1}$

\section{Resumo}

Correlacionando o aspecto histórico da Escritura e a sua condição de logos, Rudolf Bultmann instaura um procedimento exegético-hermenêutico que traz como base a pesquisa histórico-crítica da Escritura e impóe a interpretação do logos como kerygma em um processo que envolve as possibilidades de conhecimento imbricadas

1 Doutorando em Filosofia pela Selinus University of Science and Literature, Inglaterra. Mestre em Filosofia pela Universidade Gama Filho, Brasil. Mestre em Teologia pela Lucent University, USA. Professor-Pesquisador e FilósofoEducador na ONG Espaço Politikón Zôon (EPZ -São Paulo) e Investigador Correspondente no Observatório Político, Portugal. E-mail: marianodarosaletras@gmail.com 
em um determinado contexto histórico-cultural e implica a necessidade de corresponder à cosmovisão da epocalidade em curso. Dessa forma, baseado na análise crítica de Paul Ricoeur, o artigo se detém na desmitologização enquanto distinção entre kerygma e mito em um movimento que se sobrepóe ao artifício mitológico e converge para a interpelação do seu sentido originário através de um processo que, afinal, requer a sua permanência sob o horizonte da interpretação. Assim, o artigo assinala que Ricoeur mostra que Bultmann prescinde da reflexão envolvendo a linguagem lato sensu como objeto, sobrepondo à linguagem do mito a linguagem da fé em um movimento que, embora pretenda se sobrepor ao sacrificium intellectus, converge, afinal, para uma construção que tende a exigir o sacrificium intellectus nas fronteiras da desmitologização e na linguagem da fé que está implicada em seu processo.

\section{Palavras-chave:}

Bultmann; Kerygma; Desmitologização; Antropologia; Ricoeur.

\section{Abstract}

By correlating the historical aspect of Scripture and its status as logos, Rudolf Bultmann introduces an exegeticalhermeneutic procedure based on the historical-critical research of Scripture and imposes the interpretation of logos as kerygma in a process that involves the overlapping possibilities of knowledge in a given historical-cultural context and implies the need to correspond to the cosmovision of the current topicality. Thus, based on Paul Ricoeur's critical analysis, the article focuses on demythologization as a distinction between kerygma and myth in a movement that overlaps the mythological artifice and converges to the questioning of its original meaning through a process that, after all, requires its permanence under the horizon of interpretation. The article points out that Ricoeur shows that Bultmann dispenses with reflection involving the lato sensu language as an object, superimposing the language of faith on the language of myth in a movement that, although intending to supersede the sacrificium intellectus, ultimately converges towards a construction that tends to demand the sacrificium intellectus in the frontiers of demythologization and in the language of the faith that is involved in its process.

\section{Keywords:}

Bultmann; Kerygma; Demythologization; Anthropology; Ricoeur.

\section{Resumen}

Al correlacionar el aspecto histórico de la Escritura y su estatus como logos, Rudolf Bultmann introduce un procedimiento exegético-hermenéutico basado en la investigación histórico-crítica de la Escritura e impone, a su vez, la interpretación del logos como kerigma en un proceso que involucra las posibilidades de conocimiento presentes en un determinado contexto histórico-cultural y que conduce a la necesidad de corresponder a la cosmovisión de la época actual. Así, a partir del análisis crítico de Paul Ricoeur, el artículo se centra en la desmitologización como distinción entre kerigma y mito en un movimiento que se solapa con el artificio mitológico y converge en el cuestionamiento de su significado original a través de un proceso que, al fin y al cabo, requiere su permanencia bajo el horizonte de la interpretación. El artículo señala que Ricoeur muestra que 
Bultmann prescinde de la reflexión que involucra al lenguaje lato sensu como objeto, superponiendo el lenguaje de la fe al lenguaje del mito en un movimiento que, aunque pretendiendo suplantar al sacrificium intellectus, finalmente converge hacia un construcción que tiende a exigir el sacrificium intellectus en las fronteras de la desmitologización y en el lenguaje de la fe que interviene en su proceso.

\section{Palabras clave:}

Bultmann; Kerigma; Desmitologización; Antropología; Ricoeur.

\section{Aspectos Introdutórios}

Se Karl Barth instaura um princípio hermenêutico que se detém no logos, sobrepondo-se ao aspecto histórico da Escritura em função da necessidade de conferir clareza ao significado do texto, tornando-o evidente na mensagem enquanto transmissão da palavra de Deus, o artigo assinala que o sacrifício do caráter histórico que se impõe a tal procedimento exegético-hermenêutico implica a sua incapacidade de estabelecer um diálogo com a Escritura enquanto revelaçáo como conjunto de verdades divinas ou mistérios manifestados por Deus aos seres humanos.

Nesta perspectiva, tendo em vista a necessidade de superar a incapacidade do princípio exegéticohermenêutico de Barth, Rudolf Bultmann institui uma correlação que envolve a pesquisa históricocrítica da Escritura e a interpretação do logos como kerygma em uma construção que atribui ao conteúdo neotestamentário o caráter de kerygma enquanto palavra de Deus que requer a fé como decisão e obediência.

Dessa forma, o artigo assinala que, convergindo para uma pregação consistente em uma proclamação cujo sentido é o ser humano enquanto ouvinte em si mesmo, o kerygma em Bultmann se sobrepóe à razão teórica em uma construção que implica o ato salvífico de Deus como acontecimento escatológico que encerra a morte e a ressurreição de Cristo através de um movimento que constitui a ocasião para a fé enquanto decisão e obediência, tanto quanto, antes, a própria condição para a sua instauração como tal.

Nesta perspectiva, baseado na análise crítica de Paul Ricoeur, o artigo se detém na desmitologização enquanto distinção entre kerygma e mito em um movimento que converge para a interpelação do seu sentido originário, assinalando que, atribuindo ao mito a condição de uma obra que encerra a pretensão humana de dispor de Deus, a sua construção enquanto artifício mitológico se sobrepóe à noção bíblicoteológica que envolve a justificação de Deus, haja vista a oposição entre a fé e a justificação e as obras e a salvação. Tal procedimento exegético-hermenêutico, contudo, conforme destaca Ricoeur, prescinde da reflexão envolvendo a linguagem lato sensu como objeto, sobrepondo à linguagem do mito a linguagem da fé em um movimento que, embora pretenda se sobrepor ao sacrificium intellectus, converge, afinal, para uma construçáo que tende a exigir o sacrificium intellectus nas fronteiras da desmitologizaçáo e na linguagem da fé que está implicada em seu processo. 


\section{Da correlação envolvendo 0 aspecto histórico da Escritura e o seu caráter de logos em Bultmann}

Contrapondo-se à abordagem de caráter histórico-filosófico, Barth instaura um princípio hermenêutico que encerra a possibilidade de compreensão através de um processo que guarda capacidade de tornar claro e evidente o significado do conteúdo do texto, preconizando uma interpretação que se sobreponha ao abismo histórico existente e possa atribuir à mensagem um caráter contemporâneo em um movimento que exclui a condição de observador do agente exegético-hermenêutico e demanda um diálogo entre este e o documento fundado no objeto, o que implica uma relação que escapa à neutralidade, haja vista o status de Deus como Deus!

Se a hermenêutica de Barth se detém no logos e nas fronteiras que encerram a possibilidade que envolve a transmissáo da palavra de Deus, a contemporaneidade como princípio se sobrepóe ao conteúdo histórico neotestamentário em um processo que atribui primazia ao logos em detrimento de sua forma histórica, convergindo para uma construção exegético-hermenêutica passível de questionamento, na medida em que sacrifica a Escritura em seu aspecto histórico em função da sua condição de logos, o que implica a necessidade de correlacionar ambos, tal como empreende Bultmann por intermédio de um movimento que instaura um procedimento exegético-hermenêutico que traz como base a pesquisa histórico-crítica da Escritura e impõe a interpretação do logos como kerygma².

O teólogo Martin Kähler, de Halle, reconheceu a impossibilidade de fundamentar a fé na açáo salvífica de Deus sucedida em Jesus Cristo, sobre os resultados inseguros e mutáveis da pesquisa científica. Por isso Kähler nega com razão a legitimidade de se perguntar pelo Jesus pré-pascal de Nazaré nos relatos dos evangelhos: o verdadeiro Cristo não é o "Jesus histórico" da moderna pesquisa cientifica, mas o Cristo pregado pelos testemunhos apostólicos. Uma geração depois de Kähler, Rudolf Bultmann retomou essa tese na convicção de que só é possível sabermos muito pouco sobre o Jesus histórico, e que a fé é despertada através da proclamação (o "querigma") das testemunhas neotestamentárias. (Kümmel, 2003, p. 41-42)

Se a investigação da Escritura encerra um movimento que demanda a correlação envolvendo a história e a teologia no processo que implica análise e compreensão, o que se caracteriza como fundamental é a correspondência entre o princípio científico da modernidade, a decomposição da construção histórico-

2 Oriundo do grego kèrygma, que tem o significado de proclamação, anúncio, pregação, kerygma consiste na "proclamação ou pregação da mensagem cristã. No NT, kerygma pode se referir ao conteúdo, evento e ofício da proclamação. Em contraste com o ensino (didachê) que exprime a revelação de Cristo de modo conceptual e lógico em doutrinas, a ênfase de kerygma recai sobre a proclamaçáo pública e a promessa e as reivindicaçóes do evento salvador." (Brown; Coenen, 2000, Glossário, LXIX)

3 Nesta perspectiva, Norman Geisler recorre a Robert Strimpe e explica que "Kahler jamais negou a confiabilidade histórica do NT. Não rejeitou a descrição geral de Cristo apresentada nas Escrituras. Ele simplesmente insistiu em que nem as fontes evangélicas nem os métodos naturalistas do historiador são adequados para produzir uma biografia verdadeira do Jesus real", o que implica, segundo Geisler em sua leitura de Strimpe, que Kähler "não negou que os evangelhos apresentam 'um retrato confiável do Salvador para os crentes”' (Geisler, 2002, p. 468). 
cultural em suas partes constituintes e unidades componentes ${ }^{4}$ e o documento enquanto revelação como conjunto de verdades divinas ou mistérios manifestados por Deus aos seres humanos.

Nesta perspectiva, o pensamento teológico de Bultmann e o seu procedimento investigativo não se tornam capazes de estabelecer a cooperação entre os elementos constitutivos do esquema em referência, convergindo para sobrepor os dois primeiros componentes ao terceiro, cuja subestimaçáo tende a comprometer a pesquisa e o seu resultado, o qual, embora carregue a pretensão de escapar às fronteiras da mitologia, ainda conserva os seus liames em um processo que deixa subentendida a distorção do "fazerse" ou "tornar-se" carne do Logos 5 , assim como em face da condição do Logos que, enquanto "palavra", se mantém sob a égide de um "paradoxo sem conteúdo":

$\mathrm{Na}$ discussão hermenêutica, da década de 50, se evidenciou que aquilo que Bultmann deduzia do NT, o querigma, a palavra de Deus, para filósofos como Jaspers, ainda era mitologia. Para muitos teólogos, no entanto, o conteúdo era muito reduzido: Para Bultmann "o logos não se torna verdadeiramente carne, mas apenas palavra" [Heinrich Schlier], uma palavra cujo conteúdo no fundo apenas é um "paradoxo sem conteúdo"; o chamado para a decisão de fé está ameaçado de se tornar lei (\$ 21,1). (Goppelt, 2002, p. 29)

Tendo como fundamento a filosofia existencial, a construção literário-teológica de Bultmann se sobrepõe aos fenômenos históricos e a sua mera descrição ${ }^{6}$, na medida em que tal processo tende a caracterizar como mito o conteúdo da mensagem neotestamentária, haja vista a incapacidade da análise histórica de possibilitar a compreensão de um anúncio como a pregação de Jesus acerca do Reino de Deus e a sua vinda iminente ${ }^{7}$. Tal compreensão implica um processo que exige o recurso ao pensamento científico

4 Dessa forma, cabe esclarecer que, segundo Bultmann, à “Historie, que poderíamos traduzir pelo termo 'crônica histórica', pertencem os fatos determinados no tempo, sujeitos à investigação e à constatação do método histórico... À Geschichte ('História') pertencem as realidades que, mesmo sem prescindir dos fatos historicamente documentados, estão no tempo mas não são temporais, no sentido de que não têm uma data, nem se encontram subjacentes à constatação da investigação histórica. Essas realidades não recaem sob o domínio da razão, mas só podem ser recebidas pela fé. À Geschichte e não à Historie, por exemplo, pertencem a criação e a redenção como acontecimentos que não podem ser objetivados. Já a crucifixão é ambivalente: indica certamente o fato que pode ser datado, de crônica histórica, da morte de Jesus, mas também o acontecimento histórico (geschichtlich) da libertaçáo do homem da escravidão do pecado e de sua reconciliação com Deus." (Mondin, 2003, p. 186-187)

5 "Escapando à condição de um mito de transmutação e à noção que envolve uma transformação que converge para a emergência de uma terceira realidade na relação que encerra Deus e o ser humano, o processo que implica a 'encarnação', baseado no acontecimento que guarda raízes na identificação expressa no 'fazer-se' carne do Lógos, converge para a participação de Deus na condição humana em um movimento que mantém correspondência com a existência histórica e uma vida pessoal.” (Mariano Da Rosa, 2019, p. 225)

6 "Segundo Bultmann, a história não é um museu de documentos antigos que devesse ser visitado de maneira mais ou menos distraída, mas um conjunto de acontecimentos que interessam direta e pessoalmente a cada um de nós. E só quem os aborda com participaçáo existencial pode compreendê-los.” (Mondin, 2003, p. 182-183)

7 Nesta perspectiva, cabe salientar que Herman Nicolaas Ridderbos atribui a Bultmann a condição de representante típico da perspectiva escatológica do evangelho, tendo em vista que defende que "deveríamos distinguir, no evangelho, entre o conteúdo revelacional propriamente dito, e a 'mitologia contemporânea' que expressa esse conteúdo essencial. De acordo com Bultmann, essa mitologia inclui a pregaçáo da proximidade do fim do mundo. Esse direcionamento para o fim absoluto se constitui no elemento essencial e permanente no conceito do reino dos céus." (Ridderbos, 2010, p. 16) 
e à instauração de uma interpretação existencial ${ }^{8}$, que assinala o verdadeiro sentido da mensagem que, emergindo da cosmovisão mítica ${ }^{9}$ que se impóe à Escritura, supera a noção de fim de mundo e restauração cósmica, encerrando a exposiçẫo da situação atual do ser humano e a necessidade de fé enquanto decisão e obediência.

Atribuindo ao conteúdo neotestamentário o caráter de kerygma enquanto palavra de Deus que requer a fé como decisão, a construção teológico-religiosa de Bultmann encerra Jesus como a última palavra de Deus $^{10} \mathrm{em}$ um movimento que tem como alvo os seres humanos em sua concreticidade existencial, na medida em que a mensagem e a teologia neotestamentária guardam raízes no kerygma pascal enquanto confissão apostólica do acontecimento da cruz através da fé pascal em um processo que se sobrepóe ao Jesus terreno e à interpretação que circunscreve o conteúdo neotestamentário à condição de mera expressão da religião humana.

8 "Interpretação existencial é, em outros termos, perguntar: Que concepção de então, a respeito da existência humana, deduzimos desse texto?" (Goppelt, 2002, p. 28)

9 Haja vista que, tal afirma Bultmann, "a mitologia expressa uma certa inteligência da existência humana. Crê que o mundo e a vida humana têm seu fundamento e seus limites em um poder que está mais além de tudo aquilo que podemos calcular ou controlar. A mitologia fala deste poder de forma inadequada e insuficiente, porque o considera como um poder humano. Fala de deuses, que representam o poder situado mais além do mundo visível e compreensível, porém fala destes como se fossem homens, e de suas açóes como se fossem açóes humanas, ainda concebe os deuses como seres dotados de um poder sobre-humano, e suas açóes como imprevisíveis, capazes de transformar a ordem natural e ordinária dos acontecimentos. Podemos dizer que os mitos dão à realidade transcendente uma objetividade imanente e intramundana. Os mitos atribuem uma objetividade mundana àquilo que é não-mundano. (Em alemão se diria: Mythos objektiviert das jenseitige zum Diesseitigen.)" (Bultmann, 2008a, p. 16-17)

10 Caracterizando a teologia de Bultmann como "liberalismo existencialista", Tillich assinala que a tentativa de transformar as palavras de Jesus em fundamento histórico da fé cristã engendra duas construçôes, a saber, a construção teológica que atribui às palavras de Jesus a condição de "ensinamentos de Jesus" e a construção teológica que mantém as palavras de Jesus sob a égide de "mensagem de Jesus". Assim, baseada na perspectiva de que as palavras de Jesus implicam a "mensagem de Jesus", Tillich esclarece que tal pensamento "nega que as palavras de Jesus sejam regras gerais do comportamento humano, regras às quais teríamos que nos sujeitar, ou que elas sejam universais e, portanto, possam ser abstraídas da situação em que foram ditas. Em vez disso, enfatizam a mensagem de Jesus de que o Reino de Deus está 'próximo' e que as pessoas que querem entrar no Reino devem se decidir a favor ou contra ele. Estas palavras de Jesus não são, então, regras gerais, mas exigências concretas. Essa interpretação do Jesus histórico, sugerida especialmente por Rudolf Bultmann, identifica o significado de Jesus com o significado de sua mensagem. Ele exige uma decisão, a saber, a decisão por Deus. E esta decisão implica a aceitação da cruz, assim como Jesus aceitou a sua cruz. Aquilo que é historicamente impossível, a saber, o esboço de uma 'vida' ou uma Gestalt de Jesus, é engenhosamente evitado usando aquilo que está imediatamente dado - a mensagem de Jesus sobre o Reino de Deus e suas exigências - e atendo-se, ao mesmo tempo, tanto quanto possível, ao 'paradoxo da cruz de Cristo'. Mas nem sequer este método pode oferecer um fundamento à fé cristâ. Ele não explica como se pode cumprir a exigência de decidir-se pelo Reino de Deus. A situação de ter que se decidir segue sendo uma situação de estar sob a lei. Não transcende a situação do AT, a situação da busca por Cristo." (Tillich, 2005, p. 396-397) 


\section{Do kerygma e a fé enquanto decisão e obediência segundo a antropologia kerygmática de Bultmann}

Sobrepondo-se à razão teórica, o kerygma enquanto pregação que consiste em uma proclamação cujo sentido é o ser humano enquanto ouvinte em si mesmo, na medida em que a pregação se torna irredutível à condiçáo de um conteúdo doutrinal passível de assimilação intelectual em uma construção que guarda possibilidade de apreensão ou, escapando ao movimento cognitivo de incorporação lógico-racional, demanda um sacrificium intelectus, haja vista que a pregação da Palavra de Deus implica um mandato Seu em um processo que envolve o Seu nome.

Consistindo em um termo cujo significado lato sensu encerra o sentido de "palavra pronunciada e anunciada", Lógos em sua construção literário-etimológica implica a palavra em sua concreticidade em um movimento que se impóe à percepção da audição ${ }^{11}$ e implica uma interpretação que a partir do referido contexto corporifica um conteúdo de caráter teológico, na medida em que "o $\lambda o ́$ yos [lógos] que Jesus proclama é ao mesmo tempo a revelação divina eterna, que exige não só um ouvido atento, mas também a compreensão da fé" (Cullmann, 2002, p. 341).

Nesta perspectiva, encerrando o Lógos enquanto Palavra que guarda possibilidade de proporcionar vida através da escuta da fé, ao kerygma como palavra anunciada por Jesus de Nazaré se impôe a Verdade em sua acepção absoluta em uma construção teológica que caracteriza a vida de Jesus de Nazaré como a encarnação do Lógos, haja vista a interpretação que assinala que se João Batista se identifica como "a voz do que clama no deserto" 12 o conteúdo do anúncio implica o próprio Lógos, que se constitui a Revelação em $S i$ e a Verdade que se autorrevela em um processo que envolve, em última instância, a Verdade em pessoa ${ }^{13}$.

Consistindo, segundo o sentido lato sensu, no anúncio da salvação, a expressão que designa a "Palavra

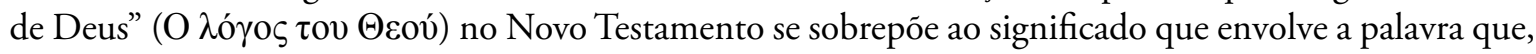
de acordo com a construção veterotestamentária, guarda correspondência com uma determinada situação, convergindo para a identificação da pregaçáo do Evangelho que, enquanto "palavra da cruz" ${ }^{14}$ ou "palavra da reconciliação" 15 , atribui ao Lógos a condição de revelação em sua acepção definitiva.

Havendo Deus, outrora, falado, muitas vezes e de muitas maneiras, aos pais, pelos profetas, nestes últimos dias, nos falou pelo Filho, a quem constituiu herdeiro de todas as coisas, pelo qual também fez o universo. Ele, que é o resplendor da glória e a expressão exata do seu Ser, sustentando todas as coisas pela palavra

11 "Quando, pois, Jesus ressuscitou dentre os mortos, lembraram-se os seus discípulos de que ele dissera isto; e creram na Escritura e na palavra de Jesus.” (Bíblia De Estudo De Genebra, Jo 2.22, 1999, p. 1232). Vide Jo 19.8.

12 "Então, ele respondeu: Eu sou a voz do que clama no deserto: Endireitai o caminho do Senhor, como disse o profeta Isaías.” (Bíblia De Estudo De Genebra, Jo 1.23, 1999, p. 1230). Vide Is 40.3.

13 "Respondeu-lhe Jesus: Eu sou o caminho, e a verdade, e a vida; ninguém vem ao Pai senão por mim." (Bíblia De Estudo De Genebra, Jo 14.6, 1999, p. 1255)

14 "Certamente, a palavra da cruz é loucura para os que se perdem, mas para nós, que somos salvos, poder de Deus." (Bíblia De Estudo De Genebra, 1Co 1.18, 1999, p. 1347)

15 "Ora, tudo provém de Deus, que nos reconciliou consigo mesmo por meio de Cristo e nos deu o ministério da reconciliação, a saber, que Deus estava em Cristo reconciliando consigo o mundo, não imputando aos homens as suas transgressóes, e nos confiou a palavra da reconciliação." (Bíblia De Estudo De Genebra, 2Co 5.18-19, 1999, p. 1378) 
do seu poder, depois de ter feito a purificação dos pecados, assentou-se à direita da Majestade, nas alturas, tendo-se tornado táo superior aos anjos quanto herdou mais excelente nome do que eles. (Bíblia De Estudo De Genebra, Hb 1.1-4, 1999, p. 1463)

Nesta perspectiva, encerrando a Palavra de Deus e a revelação que implica, o Lógos emerge na correspondência entre a construção veterotestamentária e a construção neotestamentária em um movimento que assinala que a fala de Deus envolve uma manifestação que se impóe no Filho, assim como pelo Filho, culminando na identificação absoluta entre a "Palavra de Deus" e o "Filho" em um processo que torna irredutível a revelação de Deus às palavras de Jesus, visto que a mantém atrelada também aos atos de Jesus, constituindo-se a correlação entre palavras e atos, na medida em que "o que Jesus faz é o que ele mesmo ê" (Cullmann, 2002, p. 343, grifos meus).

Correlacionando "palavras" e "história" através de uma construção etimológico-teológica que guarda raízes na concepçâo hebraica do termo que envolve "palavras" (debarim) em um processo que lhe atribui o significado de "história", a identificação de Jesus como Lógos implica a correspondência envolvendo a vida histórica de Jesus enquanto revelação de Deus e a origem de toda revelação, haja vista a condição assumida pela palavra de Deus como ação de Deus na Sua autorrevelação pela palavra criadora "no princípio".

Guardando a identificação envolvendo o Lógos de Deus e a vida de Jesus, a "Palavra", no sentido que implica a "revelação", emerge sob a acepção de denominador comum entre a criação e a vida humana de Jesus que em sua concreticidade corresponde à revelação de Deus em seu ápice através de uma construção teológico-literária assinalando que assim como houve a recusa da revelação de Deus na criação, com o povo de Israel se opondo aos profetas e à sua palavra, da mesma forma, Jesus sofre a rejeição do povo de Deus rebelde ${ }^{16}$.

Sobrepondo-se ao Lógos estóico abstrato e ao Lógos mitológico, o Lógos que se torna ser humano em Jesus de Nazaré encerra a revelação última de Deus ao mundo enquanto tal em uma construção teológicoliterária que, por este motivo, como Verbo feito carne, implica um universalismo que escapa ao sincretismo e carrega a autenticidade de uma ideia que, embora seja similar em relação à terminologia, diverge em relação aos pensamentos imbricados em um processo que guarda possibilidade de manter correspondência com o Lógos enquanto hipóstase e com o Lógos personificado, caracterizando-se, contudo, como o Lógos

16 Nesta perspectiva, alcança relevância a observação de Leonhard Goppelt, que esclarece: “Jesus não anuncia a Israel um Deus até então desconhecido, como o fizera Simão, o Mágico, em relação aos samaritanos. Anuncia a Israel a vinda de seu Deus, o Deus dos Patriarcas; é chegada a hora de volver definitivamente a esse Deus. Não apresenta esse chamado como uma proclamação genérica. Desenvolve-o, muito antes, de maneira concreta, em diálogo autêntico, que não é apenas didático. Confronta-se com Israel, e no diálogo com os representantes de Israel é que sua doutrina e o seu destino tomam forma. Age em Israel realmente como o último enviado na parábola dos lavradores maus (Mc 12,1-12 par). A parábola foi formulada ex eventu nos evangelhos, mas, na realidade, ela se refere aos dias terrenos de Jesus e interpreta o seu caminho.

Tão logo tivermos visualizado esses contornos da atividade terrena de Jesus, descobriremos o seguinte aspecto teológico: Não compreenderemos o sentido da atuação de Jesus, se o separarmos do diálogo com Israel e transformarmos sua pregação em mensagem abstrata, dirigida ao homem, como em grande parte ocorreu com Bultmann." (Goppelt, 2002, p. 65) 
que, fundado na pessoa histórica de Jesus de Nazaré, se impóe como irredutível à noção do helenismo sincrético e à concepção do judaísmo helenístico ${ }^{17}$.

Se o pensamento grego se detém no Lógos em uma construção etimológico-filosófica que encerra plena exatidão em seu aspecto formal, longe de caracterizar uma interpretação capaz de expressar o conhecimento da verdade tal perspectiva se limita a assinalá-lo e indicá-lo, na medida em que o Lógos feito carne se lhe escapava, caracterizando-se o Lógos bíblico-teológico neotestamentário como uma visão universalista, haja vista que guarda possibilidade de identificar Cristo através de um conteúdo mediante o qual o paganismo transmite uma verdade.

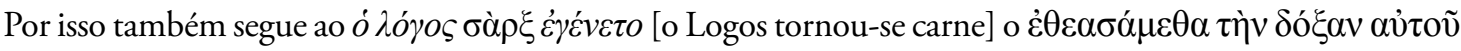
[contemplamos a sua glória] (1.14). Esse $\dot{\varepsilon} \theta \varepsilon \alpha \sigma \alpha ́ \mu \varepsilon \theta \alpha$ [contemplamos] não designa o "testemunho ocular" no sentido da informação histórica; pois nesse sentido também os judeus descrentes eram testemunhas oculares, e, náo obstante, nada viram da $\delta$ ó $\xi \alpha v$ [glória]. O sujeito do $\theta \varepsilon \tilde{\sigma} \sigma \theta \alpha \mathbf{~ [ c o n t e m p l a r ] , ~ p o r e ́ m , ~ n a ́ o ~}$ são apenas os contemporâneos crentes (os primeiros discípulos), e sim os crentes de todos os tempos; pois o revelador não foi apenas outrora, mas permanece sendo o Encarnado para sempre. Jamais a fé pode afastarse dele, como se a $\delta$ ó $\xi \alpha v$ [glória] ou a [verdade] e a $\zeta \omega \eta ́$ [vida] pudessem tornar-se visíveis diretamente ou como se a revelação consistisse num conteúdo do pensamento, para cuja transmissão a encarnação do "Verbo" teria sido apenas um expediente, agora pertencente ao passado. Por isso o papel dos crentes contemporâneos não consiste em, através de seu testemunho ocular, oferecer às geraçóes subsequentes a

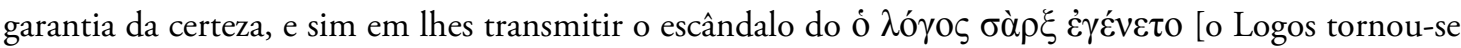
carne]. (Bultmann, 2008b, p. 507)

Instaurando a fé enquanto obediência e decisão, o querigma inaugura uma existência escatológica em um processo que implica a verdadeira autocompreensão e converge para a existência autêntica, na medida em que a proclamação do ato salvífico de Deus no acontecimento escatológico da cruz encerra a possibilidade de libertar o ser humano do pecado em face da sua resposta em relação ao Cristo.

Por isso a fé não é nenhum feito humano, nenhuma "obra", mas sim "livre ato de obediência" (R. Bultmann), em virtude do qual aquele que crê se sabe "desarraigado deste éon perverso, segundo a vontade de nosso Deus e Pai" (Gl 1.4). Por causa desse ato de obediência o que crê sabe ao mesmo tempo que foi transportado "para o senhorio de seu Filho amado, no qual temos a redenção, o perdão dos pecados" $(\mathrm{Cl}$ 1.13s). (Kümmel, 2003, p. 252)

Constituindo o acontecimento escatológico em um movimento que implica a morte e a ressurreição de Cristo, o ato salvífico de Deus se impóe à proclamação que encerra o kerygma como ocasião para a fé enquanto decisão e obediência, tanto quanto, antes, a própria condição para a sua instauração como tal. Dessa forma, se a fé guarda raízes nas fronteiras do querigma enquanto proclamação pós-pascal, recorrer ao conteúdo histórico-científico como fundamento da sua certeza como tal é contraproducente, na medida em que encerra a sua própria verdade em uma construção teológico-existencial que implica decisão e obediência e converge para a autocompreensão da existência que inter-relaciona a fé e a sua condição

17 Cabe sublinhar que, segundo Bultmann, “a denominação de Logos para o revelador preexistente provém, não da tradição filosófica grega e sim da linguagem gnóstica” (Bultmann, 2008b, p. 442). 
sine qua non, o ser humano e o seu estado de pecaminosidade e Deus como "Totalmente Outro" através de um processo de caráter paradoxal que envolve uma existência que simultaneamente se impóe como escatológica e histórico-temporal.

A condição inalienável de uma disposição em relação ao Criador e à sua vontade, eis o que se impóe ao ser humano em um movimento que encerra a ideia de sujeição, submissão, domínio, rendição, comprometimento, o que implica uma inevitável correspondência que converge para as fronteiras que assinalam tendência, inclinação, propensão, desígnio, propósito, determinação, e que se sobrepóe à unilateralidade que prescinde da oposição em função de uma harmonia que tende a abolir o atrito e a ruptura do exercício da liberdade subjetiva em sua totalidade finita e afirma a dialética vital imbricada na relação entre o ser humano e Deus. (Mariano Da Rosa, 2020, p. 180)

Atribuindo simultaneamente ao ser humano a condiçáo de justificado e a condição de pecador, o paradoxo da existência escatológica mantém correspondência com a autocompreensão da fé enquanto decisão e obediência em um movimento que implica um encontro com Jesus como açáo salvífica de Deus através do kerygma como um processo que possibilita a transformação da existência e que envolve o conhecimento de Deus enquanto "Deus-que-determina-a-existência-humana", na medida em que assinala uma experiência existencial que somente se torna passível de apreensão pela fé em uma construção teológico-existencial cujo entendimento, emergindo de uma nova autocompreensão, guarda relação com a mediação da palavra enquanto tal e encerra a instauração de uma autêntica existência ${ }^{18}$.

Consistindo em um trabalho teológico fundamental, a compreensão do kerygma requer a tradução de seu conteúdo segundo as possibilidades de conhecimento imbricadas em um determinado contexto histórico-cultural e implica a necessidade de corresponder à cosmovisão da epocalidade em curso em um processo que envolve a superação de uma construção literário-teológica que se mantém sob a égide de categorias e paradigmas que escapam à inteligibilidade, na medida em que são incapazes de produzir a autocompreensão do ser humano enquanto tal na contemporaneidade.

Escapando ao significado envolvendo um construto doutrinal que se impóe à apreensão mediante um processo lógico-racional ou através de um movimento que implica um sacrificium intellectus, o kerygma consiste em uma proclamação cujo alvo é o ser humano em sua ipseidade em uma construção que encerra a palavra da Cruz como o verdadeiro escândalo, que se sobrepóe, dessa forma, ao caráter da mensagem bíblico-eclesial enquanto conteúdo destituído de sentido para a sociedade contemporânea.

Desde logo, é certo que a desmitologização adota como critério a visão moderna de mundo. Porém desmitologizar não significa recusar a escritura em sua totalidade ou a mensagem cristã, senão que eliminar de uma e de outra a visáo bíblica de mundo, que é a visão de uma época passada, com demasiada frequência ainda mantida na dogmática cristã e na pregação da Igreja. Desmitologizar supóe negar que

18 Na medida em que, "sobrepondo-se às representaçóes Deus encontra-se além das fronteiras da palavra em uma relação que, tendo em vista o seu caráter inefável, pressupóe a imediatez da compreensão e converge para um conhecimento da verdade irredutível à experiência lógico-racional em um movimento transracional que implica a incapacidade do entendimento diante da totalidade da visão." (Mariano Da Rosa, 2018, p. 67-68) 
a mensagem da Escritura e da Igreja estão ineludivelmente vinculadas à uma visão de mundo antiga e obsoleta. (Bultmann, 2008a, p. 29)

Se a pureza da mensagem da revelação e a sua inteligibilidade se correlacionam como condição sine qua non para o processo de desmitologização ${ }^{19}$, a subestimação do fundamento histórico-cultural e do aspecto que se sobrepóe ao caráter natural da existência humana atribui preeminência ao acontecimento salvífico que se impõe ao kerygma e demanda fé enquanto decisão e obediência ${ }^{20}$.

\section{0 kerygma e o processo de desmitologização na construção exegético-teológica de Bultmann segundo Ricoeur}

Conforme mostra a tradição sinótica, a comunidade primitiva retomou a pregação de Jesus e continuou a anunciá-la. E na medida em que o fez, Jesus tornou-se para ela o mestre e profeta. Mas ele é mais: é, ao mesmo tempo, o Messias; e assim ela passa a anunciar - e isso é o decisivo - simultaneamente a ele mesmo. Ele, antes o portador da mensagem, foi incluído na mensagem, é seu conteúdo essencial. $O$ anunciador tornou-se o anunciado (Bultmann, 2008b, p. 74, grifos do autor).

Se Jesus Cristo consiste na fala de Deus, Kerygma encerra a condição que implica anúncio de uma pessoa em um processo que se sobrepóe ao caráter de uma interpretação de texto e demanda a sua expressão por intermédio de um testemunho, trazendo como base as narrações em um movimento que posteriormente tende à construção textual da confissão de fé da comunidade, que assinala que "o acontecimento por excelência é um evento linguístico e este evento linguístico é o querigma (kerygma), a pregação do Evangelho. O significado do evento original dá testemunho de si mesmo no acontecimento presente pelo qual o aplicamos a nós mesmos num acto de fé" (Ricoeur, 1987, p. 34).

A possibilidade de crer ao escutar e ao interpretar um texto, eis o que se impóe à comunidade, desde o período pós-apostólico até a contemporaneidade, na medida em que, escapando à condiçáo de

19 Ou demitologização (em alemão, Entmythologisierung), implica um processo baseado no princípio de que o mundo do pensamento do NT em sua totalidade é de caráter mitológico, guardando concepçóes que mantém correspondência com a apocalíptica judaica e o gnosticismo. Tal perspectiva remete ao século XIX e a David Friedrich Strauss (18081874), discípulo de Hegel, que, na obra Vida de Jesus (1835), afirma a presença de elementos míticos no NT e atribui ao cristianismo a condição de resultado de uma construção mítico-religiosa de Jesus. Dessa forma, Bultmann conclui que "o que é necessário, portanto, é demitologizar o kerygma cristão, não removendo toda a matéria que pudesse ser considerada ofensiva, mas, sim, remover as antigas pedras do tropeço a fim de permitir que a verdadeira ofensa da cruz e da ressurreiçáo faça seu pleno impacto. Isto porque é esta última que permite ao homem ser liberado da vida da carne e que lhe dá a possibilidade de entender a sua existência” (Brown; Coenen, 2000, Glossário, LIX).

20 Nesta perspectiva, "Os próprios discípulos de Bultmann constatavam: 'Jesus Cristo transformou-se (em Bultmann) em mero fato salvífico e deixa de ser pessoa.' [Günther Bomkamm] E esse fato salvífico, que apenas é um 'paradoxo sem conteúdo, é que me deve dominar e chamar-me à fé?... Será que aqui a exigência de fé não está ameaçada de se transformar em lei, à qual eu devo obedecer? Jamais um fato, seja ele um fato histórico ou um fato salvifico, pode chamar-me à fé, mas somente uma pessoa viva, concreta'. [Heinz Zahmt] Mas será que o Jesus terreno realmente pode fundamentar — tanto no passado quanto no presente — a fé de outros, através de sua 'fé'?” (Goppelt, 2002, p. 46-47) 
testemunhas oculares, aos seus integrantes cabe o papel da audição como fides ex auditu, tendo em vista o caráter hermenêutico que implica a relação envolvendo o próprio Novo Testamento em uma construção que converge para uma interpretação da interpretação.

Caracterizando-se como uma nova letra, uma nova escrita, o Kerygma consiste também em um Testamento, guardando correspondência com a condição de interpretante em uma relação que implica o Antigo Testamento, tanto quanto a vida e a realidade inteira, constituindo-se uma construção textual disposta propriamente à interpretação em seu sentido literal em um processo que o encerra como base teórico-conceitual para a produção dos significados alegórico, moral, anagógico.

Tornando-se um texto, uma letra, o Evangelho, enquanto tal, guarda tanto uma diferença como uma distância em relação ao acontecimento que emerge como objeto de sua proclamação, convergindo para a instauração de uma separação progressiva entre a primeira testemunha e os seus ouvintes que traz como fundamento o viés espaço-temporal em um processo que assinala a incorrespondência lógica envolvendo o locus originário e o locus secundário através de um movimento que interpõe um abismo histórico-cultural abrangendo o contexto apostólico e a modernidade.

Se o Novo Testamento enquanto testemunho encerra uma composição que envolve uma narração que guarda correspondência com uma comunidade confessante em uma construção que inter-relaciona culto, pregação e expressão de fé, a relação da comunidade contemporânea em seu contexto cultural histórico-científico com o objeto da sua fé demanda a interpretação da confissão da sua fé em um processo que possibilita a sua compreensão e converge, dessa forma, para a apreensão do Kerygma que traz em seu conteúdo.

Decifrar a Escritura, é decifrar o testemunho da comunidade apostólica; nós relacionamo-nos com o objecto da sua fé através da confissão da sua fé. É, pois, ao compreender o seu testemunho que eu recebo igualmente aquilo que, no seu testemunho, é interpelação, kerigma, "boa nova". (Ricoeur, 1988, p. 377)

Detendo-se no acontecimento em si, a desmitologizaçáo encerra a finalidade de concretizar a intenção do texto em um processo que implica a interpretação kerigmática, na medida em que envolve o retorno à condição originária do Evangelho através de uma mensagem que, perfazendo a verdadeira fala de Deus, não pode permanecer circunscrita às fronteiras da representação mitológica do mundo e do falso escândalo da sua estrutura literário-teológica, mas deve expor e revelar em sua totalidade a loucura de Deus por intermédio de Jesus Cristo, Deus-Filho, como o verdadeiro escândalo.

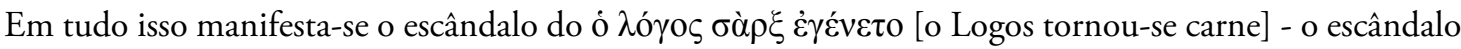
que consiste no fato de que o revelador aparece como ser humano que náo deve demonstrar perante o mundo sua afirmação de ser o Filho de Deus. Pois a revelação é o juízo sobre o mundo; ela tem que ser percebida por ele como ataque, como escândalo, enquanto o mundo não abrir máo de seus critérios. (Bultmann, 2008b, p. 477-478)

Baseado na relaçáo envolvendo crer e compreender e compreender e crer em um processo que implica uma necessidade recíproca entre ambos, o círculo hermenêutico para o qual converge o processo de desmitologizaçáo se sobrepóe ao caráter psicológico e à primazia do objeto de fé em face da fé e à preeminência da exegese e do seu método diante da leitura pura do texto, haja vista a perspectiva metodológica, que institui um círculo 
cujo movimento impõe uma regulação entre objeto e fé e método e compreensão, que assinala a instauração de uma hermenêutica que traz como fundamento o anúncio do conteúdo sobre o qual o texto se detém em uma construção que torna a compreensão a sujeição à sua mensagem.

Convergindo para atribuir à essência do sentido do texto a função de regulação e controle da sua compreensão, Bultmann se contrapóe à Dilthey e à perspectiva que atrela o referido processo à capacidade de apreensão de uma expressão da vida, na medida em que confere ao objeto da fé o poder de dirigir e governar a compreensão por intermédio de um processo que encerra o primado do objeto e do sentido em relação à compreensão em um movimento que implica a própria compreensão e o trabalho exegético, pressupondo o círculo hermenêutico como condição fundamental e estabelecendo a correspondência entre objeto e compreensão do texto ${ }^{21}$.

A fé naquilo de que se trata no texto deve ser decifrada no texto que fala dela e na confissão de fé da igreja primitiva que se exprimiu no texto. É por isso que há um círculo: para compreender o texto, é preciso crer naquilo que o texto me anuncia; mas aquilo que o texto me anuncia não é dado em nenhum outro sítio senão no texto. É por isso que é preciso compreender o texto para crer. (Ricoeur, 1988, p. 379)

Se a desmitologização implica a distinção entre Kerygma e mito em um movimento que, detendose na letra, se sobrepóe ao artifício mitológico que caracteriza a construção textual, à função positiva da referida operaçáo impóe-se a interpelação como o seu sentido originário através de um processo que não se sujeita à fixação em uma expressão objetiva e, dessa forma, requer a sua permanência sob o horizonte da interpretação ${ }^{22}$.

Se inicialmente a desmitologização implica a eliminação do caráter pré-científico da perspectiva cosmológico-escatológica da construção literário-teológica primitiva, posteriormente envolve o processo que encerra a relação entre as representaçóes objetivas do mito e a compreensão de si que através do seu conteúdo transparece e expóe a intenção do mito em um movimento que pretende traduzir o sentido da condição humana em face do seu vínculo de dependência fundamental diante do que se impóe ao limite e à origem do seu mundo.

Consistindo em um processo de redução do além ao aquém, o mito se sobrepóe à condição de um negativo da ciência em um movimento que implica uma objetivação e uma mundanização que se impóe sobre a sua origem e o seu fim enquanto realidades que escapam à dimensão do cognoscível e do tangível através de uma construção que envolve uma projeção que, como um instrumento de mediação, se detém

21 Nesta perspectiva, cabe salientar que "aqui Bultmann está perfeitamente de acordo com Karl Barth, quando este dizia, no comentário da Epistola aos Romanos, que a compreensão está sob o comando do objecto da fé. Mas aquilo que distingue Bultmann de Barth, é que o primeiro compreendeu perfeitamente que este primado do objecto, este primado do sentido sobre a compreensão, apenas se exerce através da própria compreensão, através do trabalho exegético." (Ricoeur, 1988, p. 379)

22 Dessa forma, convém expor que, "contra a crítica bultmaniana, Ricoeur sublinha com força que é indispensável questionar o funcionamento da linguagem bíblica e seu modo linguístico de referência à transcendência. Opóe-se à redução do texto das escrituras em um núcleo kerigmático despojado de sua forma narrativa e à desconstrução da linguagem simbólica da Bíblia em uma construção conceitual não mitológica, mesmo que fosse o existencialismo de Heidegger." (Amherdt In: Ricoeur, 2006, p. 23) 
no âmbito da representação, constituindo-se uma etapa da operação que guarda correspondência com a intenção do mito e tende, em nome da sua restituiçáo, a se sobrepor ao movimento que pretende o esgotamento do sentido da realidade por intermédio de uma construção de caráter técnico-cientifico.

Todo o empreendimento de Bultmann se joga entáo sobre o postulado de que o próprio kerigma quer ser desmitologizado. Já não é, por consequência, o homem moderno, educado pela ciência, que conduz o jogo; já não é o filósofo e a sua interpretação da existência aplicada ao universo dos mitos. É o núcleo kerigmátíco da pregação originária que, não só exige, mas inicia e póe em movimento o processo de desmitologização. (Ricoeur, 1988, p. 381)

Se converge para a desmitologização, o Kerygma, sob a acepção de pregação originária, encerra em si a necessidade de instaurar e desenvolver o movimento que a implica e que remete à narrativa da criação do Antigo Testamento em relação à cosmologia sagrada babilônica, como também ao "nome de Yavé" em relação às representaçôes do divino, desde Baal até os seus ídolos, na medida em que em ambos os casos a construção converge para a desmitologização, tal qual o processo que guarda correspondência com o Novo Testamento diante das representações mitológicas que caracterizam principalmente a escatologia judaica e os cultos de mistério.

Nesta perspectiva, cabe sublinhar o trabalho do Apóstolo Paulo no processo de desmitologização em uma construção de caráter antropológico que guarda relação com a mitologia cósmica através de um movimento interpretativo que encerra conceitos como "mundo", "pecado", "carne", o que implica a redução das imagens que cumprem a função de expressar o seu conteúdo ${ }^{23}$. Correspondentemente, tal operação emerge do tratamento desenvolvido pelo Apóstolo João em face das representaçóes escatológicas, na medida em que identifica Jesus Cristo como o começo do futuro e o agora crístico como a raiz da nova época, convergindo para uma construção que instaura uma desmitologização que guarda correspondência com a esperança cristã e traz como fundamento a relação entre o futuro de Deus e o presente.

A pregação escatológica de Jesus foi conservada e continuada pela comunidade cristã primitiva em sua forma mitológica. Porém muito rapidamente começou o processo de desmitologizaçáo, parcialmente com Paulo e radicalmente com João. O passo decisivo o deu Paulo ao declarar que o trâmite do velho mundo ao novo não era uma questão futura, senão que se havia produzido com a vinda de Jesus Cristo. "Porém ao chegar à plenitude dos tempos, enviou Deus a seu Filho" (Gl. 4.4). (Bultmann, 2008a, p. 26)

Atribuindo ao mito a condição de uma obra que encerra a pretensão humana de dispor de Deus em uma construção que se sobrepõe à relação que implica receber a justificação de Deus, Bultmann sublinha a oposição entre a fé e a justificação e as obras e a salvação em um movimento que, respectivamente, assinala a entrega de si como a renúncia à vontade de dispor de si mesmo e ao exercício da soberania da

23 Assim, analisando o trabalho exegético-hermenêutico de Bultmann em relação à construção teológica do Apóstolo Paulo, Ridderbos afirma que "não são as idéias escatológicas, mas sim, as percepçóes antropológicas, expressas por meio delas, que constituem o cerne da pregação de Paulo. Não é a idéia de fim de mundo, mas a maneira pela qual o homem é confrontado existencialmente com o agir e falar de Deus, em Jesus Cristo, que constitui a substância desmitologizada dessa escatologia." (Ridderbos, 2004, p. 38) 
sua existência ${ }^{24}$. Tal processo se contrapóe ao mitólogo, ao cientista e ao filósofo, na medida em que a possibilidade de se deter no acontecimento crístico e nos atos de Deus traz como fundamento a fé e a perspectiva de dependência que está imbricada em sua decisão e que guarda correspondência com um ato que dispóe dele próprio, possibilitando a instauração da desmitologização que, em sua dinâmica circular, abrange uma operação capaz de reunir todas as suas formas, a saber, ciência, filosofia e fé. Conclusão: "Toda a obra exegética e teológica de Rudolf Bultmann é o realizar desse grande círculo onde a ciência exegética, a interpretação existencial (existential) e a pregação de estilo paulino-luterano trocam os seus papéis." (Ricoeur, 1988, p. 383)

\section{Aspectos Conclusivos}

Sobrepondo-se ao caráter mitológico, a "significaçâo" dos "enunciados mitológicos" implica a possibilidade de um discurso que encerra a finitude tanto do mundo como do ser humano em relação à transcendência de Deus e ao seu poder através de uma construção que atribui ao referido conteúdo a condição da própria significação dos mitos escatológicos em um processo que impóe um sentido que escapa ao horizonte mitológico a noção que envolve um "ato de Deus" e abrange "Deus como ato", assim como a noção que envolve a "fala de Deus" e abrange o "chamamento da fala de Deus", na medida em que Bultmann afirma a concepçáo de que o chamado de Deus mediante a Palavra de Deus tem como fim o chamado do ser humano ao Eu verdadeiro em um movimento que assinala o agir de Deus enquanto acontecimento do chamamento e da decisão como o elemento não mitológico da mitologia e a sua significaçáo.

Se o transcendente enquanto o completamente outro consiste no "objeto" que se impóe ao pensamento sob a égide suprema, a sua representação implica um processo que encerra objetividade e mundaneidade, na medida em que constitui uma objetivação que envolve o que se caracteriza como limite e fundamento e como tal se mantém em uma construção que abrange "a mundanização do além no aquém" (Ricoeur, 1988, p. 380).

Atribuindo relação de correspondência entre "mito" e "ilusão transcendental", a interpretação de Ricoeur estabelece um diálogo com as similaridades envolvendo Bultmann e Kant e mantém correspondência com a palavra que designa representação (Vorstellung) em uma construção na qual tal termo identifica as "imagens do mundo" cujo conteúdo é utilizado pelo ser humano no exercício do pensamento em relação ao transcendente em um processo que se caracteriza, em suma, como "ilusório"

24 "Nesta perspectiva, constituindo-se a última hora ou o tempo do fim, Jesus chama à decisão que, convergindo para a radicalidade, impóe a escolha entre Deus ou o mundo, que demanda a renúncia de tudo que o representa e o implica em um processo que envolve a própria negação de si como condição para o ser humano tornar-se discípulo, haja vista a incompatibilidade fundamental entre Deus e o seu reinado e o mundo e os seus bens em uma construção que assinala que o vínculo com este último produz efeitos capazes de reduzir o poder de decisão e obliterar o exercício da liberdade que encerra como tal, na medida em que o reinado de Deus requer a disposiçáo sacrificial sem medida do seu seguidor." (Mariano Da Rosa, 2020, p. 169, grifos meus) 
Caracterizando como "conteúdo" idêntico e único em relação à fé tanto o seu objeto quanto o seu fundamento ${ }^{25}$, Bultmann mantém sob o mesmo horizonte epistêmico-cognitivo aquilo que se crê, aquilo por intermédio do que se crê e aquilo que se faz crer em uma construção literário-teológica que atribui ao enunciado da justificação da fé a condição de núcleo de caráter não mitológico, constituindo-se o "Evangelho no Evangelho", segundo Ricoeur. Tal análise expóe que, detendo-se em noçóes como "ato de Deus", "palavra de Deus" e "futuro de Deus", Bultmann as identifica como enunciados de pura fé em um movimento que assinala o comprometimento do sentido implicado em cada uma de suas expressóes, permanecendo imune tal linguagem da fé ao processo investigativo que submete o mito e a sua linguagem à desconstrução enquanto procedimento capaz de alcançar o cerne ou o âmago do Evangelho.

Criticando a desmitologização preconizada por Bultmann, Ricoeur condena sua distinção ingênua entre as expressóes míticas objetivantes e as formulaçôes não míticas da proclamação cristã. Para essas últimas, Bultmann não propóe nenhuma teoria de interpretação e chega diretamente à adesão da fé. Ora, a decisão existencial só pode ser tomada autenticamente se o processo de interpretação e os meandros explicativos exigidos pela linguagem da Escritura tiverem permitido aos textos desdobrarem fielmente sua significação. (Amherdt In: Ricoeur, 2006, p. 48)

Sobrepondo à linguagem do mito a linguagem da fé, o pensamento de Bultmann em sua construção literário-teológica converge para uma análise crítica que se circunscreve ao horizonte da "objetivação", o que implica um movimento que não se dispóe a tornar a linguagem lato sensu objeto de reflexão em um processo que impóe aos enunciados de pura fé um sentido que envolve a vontade e a sua condição de renúncia em relação a si própria, na medida em que é tal acontecimento que possibilita a experiência do significado do "ato de Deus" enquanto "ordem e dom, nascimento do imperativo e do indicativo (visto que sois conduzidos pelo espírito, caminhai segundo o espírito).” (Ricoeur, 1988, 384, grifos do autor).

Detendo-se no horizonte da "objetivação", Bultmann prescinde da reflexão envolvendo a linguagem lato sensu como objeto, sobrepondo à linguagem do mito a linguagem da fé em um movimento que implica, inclusive, a possibilidade que envolve a retomada do mito a título de símbolo ou de imagem e converge para uma construção analógica que encerra, em última instância, o personalismo teocêntrico da teologia protestante no processo de superação da teologia natural do catolicismo enquanto hipóstase da cosmologia.

A interpelação pessoal de Deus em um movimento que encerra um encontro que guarda correspondência com uma relação de amizade e implica uma autoridade que se mantém sob a égide da paternidade implica, sob a acepção de expressões "personalistas", uma construção literário-teológica que expóe um modo de falar de caráter analógico, na medida em que traz como fundamento a relação do tipo "Eu-Tu" em um processo envolvendo um personalismo teocêntrico que, sobrepondo-se à teologia católica e a sua base naturalista, torna-se um movimento que, contudo, segundo Ricoeur, tende a não escapar ao exercício de uma reflexão crítica referente à operação de transposição envolvendo o tu da esfera humana à esfera divina instaurada sob a égide da analogia.

25 Segundo Ricoeur (1988), tal concepção é baseada na perspectiva de Wilhelm Hermann (1846-1922), teólogo protestante alemão liberal e professor de Barth e Bultmann, cujo ensino afirma a necessidade de que a fé seja fundamentada mais na experiência direta da realidade da vida de Cristo do que na doutrina. 
Nesta perspectiva, se não há uma reflexão crítica e um questionamento envolvendo a relação entre a analogia e o recurso ao simbolismo do mito, a questão da "significação" das suas representaçôes converge para o seu comprometimento enquanto objeto de pesquisa, haja vista a diluição da sua razão de ser em uma construção literário-teológica que, segundo Ricoeur, exige na linguagem da fé o sacrificium intellectus que Bultmann tem a pretensão de abolir na superação da linguagem do mito em um processo que encerra a necessidade de abordar a linguagem e a interpretação em um movimento de problematização de caráter radical, de forma correspondente à desmitologização enquanto distinção entre kerygma e mito, e interpelação do seu sentido originário, o que implica, em última instância, a sua permanência sob o horizonte da interpretação.

\section{Referências}

Amherdt, François-Xavier. (2006). Paul Ricoeur e a Bíblia. In: Ricoeur, Paul. A hermenêutica bíblica. São Paulo: Loyola.

Amherdt, François-Xavier. (2006). Polifonia do texto bíblico e trabalho de interpretaçáo. In: Ricoeur, Paul. $A$ hermenêutica biblica. São Paulo: Loyola.

Brown, Colin; Coenen, Lothar (Orgs.). (2000). Dicionário internacional de teologia do Novo Testamento. Tradução de Gordon Chown. 2. ed. São Paulo: Vida Nova.

Bultmann, Rudolf. (2008a.) Jesus Cristo e mitologia. Tradução de Daniel Costa. 4 ed. São Paulo: Fonte Editorial.

Bultmann, Rudolf. (2008b). Teologia do Novo Testamento. Tradução de Ilson Kayser. Santo André: Editora Academia Cristá.

Cullmann, Oscar. (2002). Cristologia do Novo Testamento. Tradução de Daniel de Oliveira e Daniel Costa. São Paulo: Editora Custom.

Ferreira de Almeida, João (Trad.) (1999). Bíblia De Estudo De Genebra. Revista e Atualizada. São Paulo / Barueri: Cultura Cristã / Sociedade Bíblica do Brasil,.

Geisler, Norman L. (2002). Enciclopédia de apologética: respostas aos críticos da fé cristã. Tradução de Lailah de Noronha. São Paulo: Editora Vida.

Goppelt, Leonhard. (2002). Teologia do Novo Testamento. Tradução de Martin Dreher e Ilson Kayser. 3. ed. São Paulo: Editora Teológica.

Mondin, Battista. (2003). Os grandes teólogos do século vinte. V. 1-2. Tradução de José Fernandes. São Paulo: Editora Teológica.

Kümmel, Werner Georg. (2003). Sintese Teológica do Novo Testamento de acordo com as testemunhas principais: Jesus, Paulo, João. Tradução de Sílvio Scheider e Werner Fuchs. São Paulo: Editora Teológica.

Mariano Da Rosa, Luiz Carlos. (2018). A oração entre as práticas mágico-religiosas do politeísmo e o relacionamento pactual do monoteísmo: da superação do determinismo da história em Mircea Eliade à presença do mistério do ser em Paul Tillich. Revista Teológica DOXIA - FABRA/PUC-Rio, Serra/ES, 3(3), 46-75.

Mariano Da Rosa, Luiz Carlos. (2019). Da prece como poder mágico-religioso entre Eliade e Mauss à oraçấo como poder escatológico-existencial entre Bultmann e Tillich. Sacrilegens - UFJF, Juiz de Fora/MG, 16(2), 204-231. 
Da correlação envolvendo 0 aspecto histórico da escritura e 0 su caráter de Logos entre o Kerygma e o processo

de desmitologização em Rudolf Bultmann segundo Paul Ricoeur

Mariano Da Rosa, Luiz Carlos. (2020). O chamado à decisão entre o conhecimento da vontade de Deus e o arrependimento na teologia escatológico-existencial de Bultmann. Revista Caminhando-UMESP, 25(3), 161-184.

Ricoeur, Paul. (2006). A hermenêutica bíblica. Tradução de Paulo Meneses. São Paulo: Ediçôes Loyola.

Ricoeur, Paul. (1987). Teoria da interpretação: o discurso e o excesso de significação. Tradução de Artur Morão. Lisboa: Edições 70.

Ricoeur, Paul. (1988). O conflito das interpretaçōes: ensaios de hermenêutica. Tradução de M. F. Sá Correia. Porto: RÉS-Editora.

Ridderbos, Herman. (2004). A teologia do apóstolo Paulo: a obra definitiva sobre o pensamento do apóstolo dos gentios. Tradução de Suzana Klassen. São Paulo: Editora Cultura Cristá.

Ridderbos, Herman. (2010). A vinda do reino. Tradução de Augustus Nicodemus Lopes e Minka Schalkwijk Lopes. São Paulo: Cultura Cristá.

Tillich, Paul. (2005). Teologia sistemática. Tradução de Getúlio Bertelli e Geraldo Korndörfer. São Leopoldo: Sinodal. 